\title{
The Largest Bankruptcy in American History
}

The Lehman Chapter 11 bankruptcy case represents the largest, most complex, multi-faceted and far-reaching bankruptcy case ever filed in the United States. ${ }^{1}$ As the parent corporation, Lehman Brothers Holding Incorporated (LBHI) managed and directed the affairs of the enterprise, which consisted of a global network of approximately 8,000 subsidiaries and affiliates, with offices in every major centre in the world engaged in the various business activities of Lehman, ranging from derivatives, commercial loans, underwriting, real estate, bank ownership and broker/dealer operations. LBHI managed the cash generated by the enterprise. All such cash was placed in cash concentration accounts at LBHI every night, and then LBHI disbursed the required cash to all its subsidiaries and affiliates.

The Examiner, Anton Valukas, was appointed by the Bankruptcy Court for the Southern District of New York on 16 January 2009 to report on the causes of the Lehman bankruptcy as directed by the Court. ${ }^{2}$ He concluded that Lehman was unable to maintain confidence because it made a series of business decisions that left it with a heavy concentration of illiquid assets of deteriorating value in commercial and residential real estate. He found that the policies Lehman followed were in error, but that they fell within the 'business judgement rule'. However,

the decision not to disclose the effects of those judgements does give rise to colorable claims against senior officers who oversaw and certified misleading financial statements - Richard Fuld and its Chief Financial Officers, Christopher O'Meara, Erin M Callan and Ian T Lowitt and against Lehman's external auditor Ernst \& Young ... for its failure to question and challenge improper or inadequate disclosures in those financial statements.

He defines a 'colorable claim' as one for which the Examiner has found that there is 'sufficient credible evidence to support a finding by a trier of fact' to determine whether the claims are valid. That applies to the use of Repo 105, since their sole 
purpose was balance sheet manipulation. ${ }^{3}$ After the bankruptcy process was completed, there was no further investigation of the Examiner's conclusions about the 'colorable' claims. None of these have been investigated further by any court or by the regulators, and no action has been taken against any of the four named individuals. This chapter explores the main issues cited as the cause of the bankruptcy and the reasons why Lehman conducted its business in the way it did without any proper oversight.

The Examiner pointed out that Lehman's business model was not unique; all of the major investment banks at that time used a high-risk, high-leverage model, which depended on retaining the confidence of the counterparties. Lehman maintained about $\$ 700 \mathrm{bn}$ of assets and corresponding liabilities on capital of about $\$ 25 \mathrm{bn}$. Lehman borrowed heavily to meet its cash needs, creating a high debt-to-equity ratio. The assets were generally long-term, whilst the liabilities were short-term; for example, Lehman financed most of its balance sheet in the short-term repo market to the tune of over $\$ 200 \mathrm{~m}$. per day in 2008. It relied on short-term secured financing to conduct its daily operations. Vast sums of money were borrowed each day so that the company could stay open for business. They had to be confident that Lehman was in a position to repay in order to roll over its daily funding. At that time, the other investment banks operated in the same way, but after the collapse of Lehman Brothers, it is not surprising that investment banks no longer use that business model.

As noted above, Lehman decided to adopt an 'aggressive growth strategy', take on more risks and increase its leverage. The company continued to invest in commercial and residential real estate, despite the growing problems in these markets, which it failed to take on board, in the belief that they would win in the end, as they had done in the late 1990s by surviving the Russian debt crisis. The Examiner quotes one of the board members, who reported that management advised that 'virtually all subprime originators have cut back on their operations or gone out of business', but that it was management's view that 'the current distressed environment provides substantial opportunities as it did in the late $1990 s^{3}{ }^{4}$

\section{The use of Repo 105}

The extent of such investments was deliberately concealed by the Repo 105 and Repo 108 devices. To hide the extent to which LBHI was leveraged, the company developed and used a version of Repo 105 and Repo 108 in 2001, but used the 
device much more extensively in 2007 and 2008, as analysts and rating agencies began to focus on the leverage ratios of investment banks.

At first sight, these appear to be the standard repurchase and resale (repo) transactions, which investment banks use to obtain short-term financing. Usually with a repo, one party sells an asset (usually fixed income securities) to another party at one price at the start of a transaction and is committed to repurchase the asset from the 'buyer' at a different price at a future date, usually overnight or within 30 days. Because of the commitment to repurchase, the buyer has only temporary use of those assets, and the seller only has temporary use of the cash proceeds of the sale. The difference between the price paid by the buyer at the start of the repo and the price he receives at the end is the return on the cash he is effectively lending to the seller. In the repo agreements, this return is quoted as the repo rate, a percentage per annum.

One of Lehman's former senior employees dismissed the 'obsession' the Examiner had with Repo 105 as simply that. In his view, the Examiner did not understand that it differed little from the UK 'bed and breakfasting', which applied to share transactions in which shares were sold one day and reacquired the following morning, but the term is now used more generally to cover arrangements whereby a person sells an asset only to buy it back again a short time later. The purpose in the UK was to create a disposal for the purposes of avoiding capital gains tax (CGT) but to regain ownership of the asset. The taxpayer established a loss at the date of the transaction. The rules have now changed and it is no longer possible to buy the same shares back in under 30 days if the taxpayer wishes to crystallize a capital gain. The new rules came into effect in April 2008.

Lehman used the same term Repo 105 to refer to both Repo 105 and 108, since the accounting treatment was the same, except one used fixed income securities with a minimum of 5 per cent over-collateralization (i.e a minimum of $\$ 105$ value of securities for every $\$ 100$ borrowed), and the other for equities a minimum of $\$ 108$ value of equities for $\$ 100$ cash borrowed. Lehman strayed from the standard use of repos by accounting for its repo transactions as 'sales' in order to reduce its publicly reported net leverage. Their quarterly reports did not disclose the cash borrowing from the Repo 105 transaction, that is, the company did not disclose either the cash borrowings or the obligations to repay the debt. According to the interview with Martin Kelly, former Global Financial Controller from December 2007 to September 2008, Repo 105 was used to pay off other business liabilities, thus reducing the leverage. A few days after the new quarter began, Lehman would have to borrow the necessary funds to repay the cash 
borrowings plus interest, buy the securities back and restore the assets to the balance sheet.

In its forms $10-\mathrm{K}$ and $10-\mathrm{Q}$ for the SEC, Lehman defined its 'net leverage ratio' as net assets divided by tangible equity capital. Net assets were defined as total assets, excluding cash and securities segregated and on deposit for regulatory and other purposes; securities received as collateral; securities purchased under agreement to resell; securities borrowed and identifiable intangible assets and goodwill. Tangible equity capital included shareholders' equity and junior subordinated notes. It calculated its leverage ratio by the standard method of dividing the total assets by shareholders' equity. The issue is the effect of the surge in the use of Repo 105 in 2007 and 2008, and the impact of these transactions on the firm's net leverage ratio. The Examiner placed considerable reliance on Martin Kelly, both for the extent of the use of this device and his view that 'a careful review of Lehman's Forms 10-K and $10-\mathrm{Q}$ would not reveal Lehman's use of Repo 105 transactions', which Kelly considered had as their 'only purpose or motive for the transactions ... a reduction in the balance sheet' and that 'there was no substance in the transactions. ${ }^{5}$ Other senior executives were aware of the use of Repo 105, but not the board. Neither its use nor its purpose was ever revealed to members of the board.

Lehman had began selling Repo 105 in 2001, but from mid-2007 onwards, selling its inventory positions without incurring substantial losses proved increasingly difficult. Such 'fire sales' would have led to a loss of market confidence in Lehman's valuations. Raising equity was also a problem since, although it would have improved its net leverage, it would not have solved the underlying problem of its leveraged loans and commercial and residential properties, which were falling in value by the day. Lehman turned increasingly to Repo 105. The Examiner highlights a document produced in February 2007, describing Repo 105 as a 'low cost way to offset the balance sheet and leverage impact of the current market conditions', since 'exiting large CMBS position in real estate and subprime mortgages before quarter end would incur large losses due to the steep discounts required to sell them ... As a Repo 105 would help to avoid this without negatively impacting our leverage ratios. Lehman used the cash borrowing in Repo 105 to pay various short-term liabilities, real liabilities to unrelated third parties, thereby reducing the total assets and liabilities, and thus its reported leverage ratios. The firm temporarily reduced its net balance sheet by $\$ 38.6 \mathrm{bn}$ in the fourth quarter of 2007 , by $\$ 49.1 \mathrm{bn}$ in the first quarter of 2008 and by $\$ 50.38 \mathrm{bn}$ in the second quarter of $2008 .{ }^{6}$ Lehman's publicly reported net 
leverage ratio for 30 November 2007 (fourth quarter 2007), 29 February 2008 (first quarter 2008) and 30 May 2008 (second quarter 2008) was 16.1×, 15.4× and $12.1 \times$, respectively. Without the balance sheet benefit of Repo 105 transactions, Lehman's net average ratios for the same quarterly returns would have been $17.8 \times, 17.3 \times$ and $13.9 \times$, respectively. ${ }^{7}$

When Lehman first introduced its Repo 105 programme around 2001, it was unable to find an American law firm which would provide it with an opinion letter, allowing the true sale accounting treatment under US law, so Lehman conducted the programme under the auspices of an opinion letter provided by Linklaters in London. The letter was provided for Lehman's European brokerdealer firm there on 31 May 2006. ${ }^{8}$ The Repo 105 transactions allowed Lehman to maintain its level of earning assets while reducing the size of the balance sheet. The letter analyses the implications of the Global Master Repurchase Agreement (GMRA) which Lehman Brothers International (Europe) intended to use for Repos. The letter advised that the transfer of the purchased securities to the buyer for the purchase price might, under English law, be classified as a sale involving the disposition of the seller's entire proprietary interest, as opposed to a charge. It states that 'this opinion is limited to English law as applied by the English courts and is given on the basis that it will be governed and construed in accordance with English law'. One of the assumptions in the letter was that the 'purchased securities consist of liquid securities, so that the buyer could easily dispose of purchased securities and acquire equivalent securities if it wished'. This assumption was more honoured in the breach than the observance in 2007 and 2008 by Lehman.

Finally, the opinion was described as solely being for the benefit of LBIE, although a 'copy of this opinion may be provided by Lehman Brothers to its auditors for the purpose of preparing the firm's balance sheets.' The existence and use of this letter explains why the Repo 105 transactions were conducted through LBIE.

The Repo 105 transactions were structurally and substantively identical to ordinary repo transactions, using the same documentation and with the same collateral and counterparties, making them more difficult to detect. They were also supposed to consist of liquid assets. Lehman also used US-based securities, such as assets held in US trading books for Repo 105s, a procedure which rapidly increased from late 2007 through to 2008. These were usually 'agencies, bullets ${ }^{9}$, Fannie and Freddie'. Another email, dated 20 February 2008, stated that 'we are likely to use more agency product as collateral and might even use some TIPS (Treasury Inflation Protected Securities) and discount notes. ${ }^{10}$ The method used 
was booking Repo 105 transactions through LBIE using inter-company repo transactions. These amounted to $\$ 8.3036 \mathrm{bn}$ in November $2007, \$ 14.889 \mathrm{bn}$ in February 2008, and $\$ 13.6307 \mathrm{bn}$ in June 2008 . The liquidity requirements were well known throughout the company, but were not always observed.

In January 2008, Richard Fuld made a strategic decision that Lehman would embark on a firm-wide effort to reduce its balance sheet and lower the firm-wide net leverage ratio by selling assets. But by then many of Lehman's assets, especially mortgages and real estate securities, had become difficult to sell without incurring substantial losses. In addition, investors and the rating agencies had become much more focused on leverage ratios, and Lehman was anxious not to lose its rating. The extensive use of Repo 105 was then the only way to reduce its leverage ratio. The Examiner, Anton Valukas, amassed considerable evidence, especially from internal emails, showing that Lehman had never disclosed its Repo 105 practice, but that the firm's disclosures of its cash holdings at each quarter-end further strengthens the witness statements and other evidence that Lehman used the Repo 105 for other business purposes, such as paying off shortterm liabilities. This was confirmed by Martin Kelly and also Edward Grieb, former financial controller at Lehman. ${ }^{11}$

Awareness of the use of Repo 105 was widespread throughout the firm and at every level. An email addressed to Bart McDade from Hyung Lee said: 'I am not sure you are familiar with Repo 105 but it is used to reduce net balance sheet in our government businesses around the world.' To which Bart replied (as head of equities in April 2008, but shortly to become President and Chief Operating Officer in June 2008): ' I am very aware ... it's another drug we're on. ${ }^{12}$ Valukas states that several additional emails sum up the reasons for Lehman's Repo 105. 'The firm has a function called repo 105 whereby you can repo a position for a week and it is regarded as a true sale to get rid of the next balance sheet', and 'we have been using Repo 105 in the past to reduce balance sheet at the quarter-end.'.13

\section{Use and misuse of Repo 105}

First of all, Dick Fuld denied any knowledge of the use of Repo 105 as described by the Examiner in his testimony under oath before the House Committee on Financial Services on 20 April 2010. He stated that 'another piece of misinformation was that Repo 105 transactions were used to hide Lehman's assets. That is also not true. Repo 105 transactions were sales as mandated by the 
accounting rule, FAS 140.'He also stated that the'Examiner himself acknowledged that Repo 105 transactions were not inherently improper and that Lehman appropriately accounted for those transactions with its outside auditor [Ernst \& Young] ... and that E\&Y reviewed that policy and supported the firm's application of the relevant rule, FAS 140.' Chairman Bernanke in his statement to the same committee pointed out that the Federal Reserve was 'not aware that Lehman was using so-called Repo 105 transactions to manage its balance sheet.'

In her evidence to the House Committee on Financial Services on 20 April 2010, Mary Shapiro, Chairman of the SEC, pointed out that

Lehman did indeed fund itself in large part through short-term repurchase transactions, borrowing tens of billions of dollars on a daily basis.... Accounting standards establish guidance for whether a repurchase transaction should be reported as a financing transaction (debt) or a sale, which depends in part on whether the reporting entity has surrendered control over the asset. Typically, repos are accounted for as financings (debt) as control over the assets is not fully surrendered.

Owing to the loss of confidence about Lehman's leverage in 2007 and 2008, Lehman increasingly relied on Repo 105s, which, 'unlike typical repo transactions' were 'treated as sales for accounting purposes.' Lehman temporarily removed billions of dollars of assets from its balance sheet, using the cash to pay down liabilities as a means of reducing its reported leverage, but did not disclose the fact that it treated these transactions as sales but accounted for them as transactions. She added that regulators, including the SEC, rating agencies and the Lehman board, were unaware of Lehman's use of Repo 105. It is interesting to note the differences between Shapiro's account of Repo 105 and accounting rules with Dick Fuld's statement, which seems to slide over the explanation of the complexity of FAS 140 .

In fact, the arrangements made by Lehman were more complex than Fuld's statement suggests. The rationale for counting the Repo 105 transactions as sales was that the securities were 'significantly over-collateralized' (although they were probably over-valued):

Since the lenders held collateral worth 105 per cent of the amount advanced... for debt securities, the lenders might not necessarily enforce Lehman's obligation to repurchase the inventory, since they could liquidate the collateral profitably. (Repurchases collateralized by equity securities were nominally 8 per cent overcollateralized, and called 108 per cent inside Lehman). ${ }^{14}$ 
Even if the valuations were true, this would not change the fundamental nature of the secured borrowing. That part of its inventory used as collateral was removed from the books and replaced by cash, but no debt was recorded. Using the borrowed funds to pay down other obligations, slimming down the balance sheet but improving the debt/equity leveraging, even if only by a small amount, is legitimate. But the 'two step process engaged in by Lehman would seemingly be an attempt to conceal its holdings of risky, perhaps value-impaired inventory, its large debt obligations for repurchasing that inventory and its high debt/equity leverage ratio.' ${ }^{15}$ It took some time for the Financial Accounting Standards Board to close the loophole, whereby Fuld was able to present repurchases as sales. The new rule replaced the 98 to 102 per cent which enabled Lehman to count the Repo transactions as sales because the lenders' held collateral worth 105 per cent of the amount advanced. Under the new rules, Repos will not count as sales unless it is a real transfer of the risk and reward of the asset. If that does not happen, then it is a loan and the assets remain on the borrowers' balance sheet. The full details of the new rules were not agreed until June $2014 .^{16}$

\section{Fair value accounting}

Lehman adopted fair value accounting under GAAP in the first quarter of 2007 in order to maintain the value of its assets in the eyes of its investors and competitors. Early adoption was recommended by the Financial Accounting Standards Board, and Lehman announced that they had done so in their Form 10-Q for the first quarter of 2007. If there is no market, or a declining market, for its assets, then SFAS 157 (statement of financial accounting standards) allows a company to use its judgement to determine fair value, taking into account its view as to the assumptions that market participants would use in pricing the assets. Fair value is defined as the 'price that would be received to sell or buy an asset or paid to transfer a liability in an orderly transaction between market participants at the measurement date. It allows for 'usual and customary' transactions and does not apply to forced sales. These constitute Level 1 valuations, according to the hierarchy of values created by SFAS 157 .

Level 2 valuations are those requiring other inputs besides the market price, which may not always be available. Such inputs could include quoted prices for similar assets or liabilities in active markets. More importantly, given the markets in which Lehman Brothers was operating, Level 2 includes quoted prices for identical or similar assets or liabilities in markets that are not active, that is, 
markets in which there are few transactions for the asset or liability, the prices are not current, or price quotations vary substantially either over time or among market makers, or in which little information is released to the public. These adjustments will depend on various factors relating to the asset or liability, such as its condition or location. Level 3 refers to situations where there is little, if any, market activity. Valuing these assets and reporting on them is based on the company's own views about the assumptions that market participants would use in pricing the asset or liability. Such assets or liabilities would be marked to model using discounted cash flow models or hypothetical hedge portfolios, based on knowledgeable market participants' views and assessments. The market in RMBSs and commercial real estate declined sharply throughout 2007 and 2008, when it virtually collapsed. That meant it was not possible to mark-tomarket for an increasing proportion of its assets, so that Lehman had to rely on its judgement in terms of Level 2 and Level 3 in order to assess the fair value of its assets.

Lehman, according to the Valuation and Control Report-Fixed Income Division indicated the extent to which the company went in order to try and value assets during that period. Lehman reported an increasing proportion of Level 2 and Level 3 assets in its financial statements from the fourth quarter of its 2007 fiscal year to the end of the first quarter of 2008. By the end of the second quarter of 2008, Level 1 assets had decreased substantially, and at the same time Level 2 and Level 3 assets had increased as a proportion of the firm's total assets. Lehman reported that during fiscal year 2007, its Level 3 assets increased, ending the year at 13 per cent of financial instruments and other inventory positions owned. By the end of the second quarter of 2008 the aggregate amount of Lehman's financial inventory considered Level 2 or Level 3 had decreased on a quarter-by-quarter basis, the majority of this decrease having occurred in the Level 2 category, and there was an even more substantial decrease in the amount of Level 1 assets over the same period, so that the proportion of Level 2 and Level 3 assets increased on a quarter-by-quarter basis. Perhaps Lehman was aware of the advantages of using Level 2 and especially Level 3 as the value of assets declined owing to market developments. The Level 3 valuations gave Lehman the scope to produce its own valuation of the assets.

During the earnings call on 16 June 2008, when Lehman sought to present losses of $\$ 2.8 \mathrm{bn}$ for the quarter in the best possible light, Fuld explained that Ian Lowitt, the new Chief Financial Officer replacing Erin Callan, would describe the valuation process. Lowitt summarized their asset valuation and controls, describing the work of the 'independent' Product Control Group (PCG) of 
approximately 500 finance professionals dedicated to the production, analysis and reconciliation of daily profit and loss results. With that group was a smaller unit of about 100 staff globally who verified pricing by reviewing recent sales activity for that or similar assets, making comparison with prices provided by external data providers, broker quotes, index levels and industry research reports. With regard to residential mortgages, Lowitt noted that the company had sold $\$ 11 \mathrm{bn}$ and bought about $\$ 6 \mathrm{bn}$, across the capital structure and loan types including Alt-A and subprime, 'giving us a good transparency in our pricing. ${ }^{37}$

But the analysts representing their competitors were not impressed by Lehman's valuation procedures, although they appeared to accept Lehman's replies. Prashant Bhatia, Citi analyst, mentioned the $\$ 54 \mathrm{bn}$ of residential and commercial mortgage exposure, asking: 'in rough numbers, what do you think the intrinsic value of the $\$ 54 \mathrm{bn}$ is, and was assured that it was on a mark-tomarket basis, with 'a lot of transparency, as a result of all the sales'. Bhatia also asked about the non-performing loans balances broken down by residential, commercial and real estate investment related, but the CFO replied that he did not have those figures to hand. Bill Tanona, from Goldman Sachs, pointed out that where assets were marked was 'obviously a big concern in the marketplace' especially with Level 3 assets being about $\$ 38 \mathrm{bn}$ for the quarter. He wanted to know what percentage of these assets were mortgage-related, and why a large proportion of the European market had moved from Level 2 to Level 3. Once again, the answer from Ian Lowitt was incomplete: it was too early in the process to say where mortgage and asset-backed securities were likely to be. They valued the decline in European mortgages at a 28 per cent fall in house prices, although what they saw was a decline of 7 per cent. Lehman insisted that the marks they had given were conservative. The earnings call and the responses to analysts' questions were hardly inspiring, leading Einhorn to conclude that

there is good reason to question Lehman's fair value calculations ... Lehman could have taken many billions more in write downs than it did. Lehman had large exposure to commercial real estate ... Lehman does not provide enough transparency for us to even hazard a guess as to how they have accounted for these items. ${ }^{18}$

He had taken the unusual step of announcing that he was shorting Lehman's stock on 8 April, in his presentation at Grant Spring Investment Conference. But perhaps that was not so surprising after all. If others started to short the stocks, 
then his profits would increase. But as the New York Magazine put it, Einhorn 'sees no conflict between his public moralism and the fact that he stands to profit from it.' ${ }^{\prime}$

Valukas points out that the lack of confidence in Lehman's valuations was also shown in the demands for collateral by Lehman's clearing banks throughout 2008 to cover the risks they assumed in connection with clearing and settling Lehman's tri-party and currency trades and other extensions of credit. Without this access, Lehman would be unable to carry out day-to-day operations, so Lehman sought to pledge its structured instruments, such as collateralized loan obligations to JP Morgan and Citigroup, two of its principal settlement banks. Citigroup refused to accept these assets, which they regarded as being illiquid, and found impossible to value. JP Morgan accepted Lehman's structured instruments, but insisted on additional collateral in cash. Their own analyses showed that these instruments did not have the value Lehman assigned to them.

\section{Lehman's methodology for the valuation of its assets}

The Examiner's first step was to evaluate the reasonableness of Lehman's markto-market valuations, in two distinct but related contexts. The first was to consider whether there was enough evidence to show that Lehman's valuations were 'unreasonable' for a particular asset class, such that 'the court could adjust, or even disregard, such valuations in determining the solvency of these debtors.' The second was to determine that there was sufficient evidence that the valuations were so unreasonable, and, if so, were these the product of actions of a Lehman officer, so that there was a 'colorable claim of a breach of fiduciary duty. ${ }^{20}$ The Examiner noted that the courts have assessed the reasonableness of a debtor's valuation or projection of future cash flows in the light of information available at the time the valuation was undertaken, and that the valuation of illiquid assets requires considerable judgement.

In the Bankruptcy Report, Valukas examines the valuation procedures for Lehman's commercial real estate portfolio, which included commercial mortgage loans and commercial mortgage-backed securities, backed by real estate properties generating cash flow. Lehman's intention was to syndicate, securitize and/or sell these assets to investors shortly after their origination or acquisition. Lehman's assets included highly leveraged debt or equity investments in real estate assets that Lehman intended to hold for its own account while a developer 
improved or developed the underlying asset. The investment would then be sold, along with a sale of a real asset after the development or improvement was completed. Lehman would provide bridge equity, as well as debt financing to a real estate company, enabling it to acquire particular properties of another company through a leveraged buy-out. On 31 May 2008, Lehman's Global Real Estate Group (GREG) valued its global portfolio at $\$ 49.3 \mathrm{bn}$, consisting of \$28.0bn in the United States, \$12.5bn in Europe and \$8.9bn in Asia. Given that the Examiner's focus was on US assets, the commercial real estate figures were: commercial \$15.1bn; Principal Transactions Group (PTG) \$8.5bn; and bridge equity $\$ 3.1 \mathrm{bn}$. Then virtually all in the commercial group were classified as Level 2 and the PTG and bridge equity positions were classified as Level 3. By 31 August 2008, GREG valued its commercial portfolio in the United States as $\$ 23.4 \mathrm{bn}$ with Level 1 at $\$ 15 \mathrm{bn}$, Level 2 at $\$ 20.1 \mathrm{bn}$ and Level 3 at $\$ 12.5 \mathrm{bn}$. The Examiner also reclassified $\$ 0.6 \mathrm{bn}$ of SunCal positions from PTG into the 'other' category.

Each commercial real estate business unit was responsible for valuing its assets, based on their knowledge of the development of the real estate asset. Other commercial positions were valued by those working in that section based on their understanding of how debt was trading in the applicable market. The process involved referring the valuations to the product controllers, whose role was to conduct price verification for the CRE assets. They tested the positions by inputting position-specific information into spreadsheet models, which produced an 'output' value based on calculations and formulas selected by Lehman price-testing tools. They then considered whether the variances exceeded a certain threshold. The variances were discussed with the business unit in question, and if no agreement could be reached, then the matter was referred to more senior staff and ultimately to the CFO.

The bankruptcy report notes that Mark Walsh was clear that senior management never changed the 'marks' he deemed appropriate. He found that management played an active role in resolving disputes between Lehman's trading desks and the Product Control Group as to proper valuations in late 2007 and 2008. During that time, it became more difficult for him to resolve disagreements as to a position's value, and Walsh was more inclined to "kick it upstairs" for resolution by McDade, Kirk or Lowitt. ${ }^{21} \mathrm{He}$ also stated that there never was a time when a write-down that GREG proposed was overruled or modified, or when senior officers predetermined the amount of write-downs that would be taken for a quarter, or limited the amount of write-downs GREG was allowed to take. On the basis of both Walsh's evidence and that of 
others, the Examiner found no evidence that 'senior management involvement [had] led to unreasonable valuations during the whole period. He noted that senior management became concerned with 'late breaking news' about proposed CRE write-downs more particularly in the third quarter of 2008. But even during this period, Valukas concluded that

evidence is in great conflict as to whether senior management tried to impose artificial limits on write-downs or whether more junior managers saw a management 'push-back' as management interference. The write-downs were never published, and anyway would only have amounted to $\$ 200 \mathrm{~m}$., small by comparison with the losses of $\$ 3.9 \mathrm{bn}$.

Indeed at a time when markets were collapsing, it is only to be expected that senior management would scrutinize the valuations of their assets, since they would need to be sure of the extent of the problems they faced.

The difficulties Lehman faced in valuing its commercial real estate positions arose from the changes in its strategy in 2006, when the company turned to the historically profitable commercial real estate (CRE) business, reporting at the end of 2007 that CRE assets had risen to $\$ 55.2 \mathrm{bn}$ at the end of its 2007 fiscal year, up from $\$ 28.9 \mathrm{bn}$ at the end of 2006. During July and August 2007, Lehman realized that the market for securities backed by CRE assets was 'virtually closed', although they were already committed, largely by the activities of Mark Walsh. Lehman stopped originating new loans until the end of the third quarter of 2007. However, it had already agreed to finance several large CRE deals, including Archstone, which were completed in October and November 2007. Mark Walsh was head of GREG, who reported to the head of Lehman's Fixed Income Division (FID). He and the two managers serving under him, the head of US originations, and the head of Credit Distribution served on GREG's Global Credit Committee and were responsible for approving the origination of CRE deals.

Walsh had already acquired a reputation in Wall Street as the

most brilliant real estate financier on Wall Street ... a lot of Wall Street firms tried to duplicate Lehman's commercial real estate strategy ... [Walsh] had generated more than 20 per cent of Lehman's $\$ 4 \mathrm{bn}$ in profits at the peak of the real estate boom of 2006. He introduced 'bridge equity' deals for large acquisitions such as Archstone. ${ }^{22}$

By quickly committing to fund required debt and equity, Lehman was able to obtain deals with large profits as positions were securitized and longer-term 
equity capital was raised. But that left large balance sheet positions when market conditions changed.

Bridge equity became one of Lehman's signature products, which Mr Walsh's group deployed in dozens of deals, including Tishman Speyer's $\$ 1.7 \mathrm{bn}$ purchase of the MetLife Building on Park Avenue in 2005 and Beacon Capital Partners' acquisition of the News Corporation's headquarters on the Avenue of the Americas for more than $\$ 1.5 \mathrm{bn}$ in $2006 .^{23}$

He was regarded as easily the most aggressive lender of bridge equity, the shortterm loans of equity that helped deals to complete quickly with the expectation that Lehman would replace the loan with new equity partners after the deal closed and receive the fees.

According to interviews with Mark Walsh conducted by the Examiner, he knew that it was necessary to reduce the balance sheet during the fall of 2007 with a target of $\$ 25 \mathrm{bn}$ in the USA, \$10bn in Europe and \$10bn in Asia. But by the end of the first quarter of 2008, only 13 positions had been sold in the USA, for $\$ 350.5 \mathrm{~m}$., none in Europe, and one in Asia, for $\$ 33.1 \mathrm{~m} .{ }^{24}$ Over the course of 2008 , Lehman wrote down its CRE positions by more than $\$ 3 \mathrm{bn}$. It had recognized in January 2008 that its CRE portfolio was at risk due to market conditions with the 'continuance of the capital markets meltdown', CMBS spreads had 'widened to all-time highs and investors [were] staying on the sidelines. The consequences then were that Lehman was unable to hedge its floating rate book and the mezzanine ${ }^{25}$ classes of their fixed rate loans continued to result in losses. GREG carried out a valuation review of their entire portfolio, taking into account among other issues, the lack of liquidity in the market place. ${ }^{26}$

\section{Disruptions in the market and valuation}

Geithner remarked in a speech to the Economic Club in New York that

the funding and balance sheet pressures on banks were intensified by the rapid breakdown of securitization and structured finance markets. Banks lost the capacity to move riskier assets off their balance sheets, at the same time they had to fund, or prepare to fund, a range of contingent commitments over an uncertain time horizon. ${ }^{27}$

That obviously created difficulties for Lehman's valuation of its commercial real estate assets. These were typically backed by assets already constructed, 
operating and generating cash flow. Lehman had expected to syndicate, securitize and/or sell them within a few months. But the market conditions forced the company to retain the assets on its books. Its exit strategy for these assets disappeared and inevitably the value of its assets fell with $\$ 195 \mathrm{~m}$. in write-downs in the second quarter of 2008 , with a further write-downs of $\$ 306 \mathrm{~m}$. in the third quarter of 2008.

Lehman was able to sell some of its assets and was able to use that data in determining the value of the assets but that may have given a false picture of the value of the remaining assets, since the valuations of the remaining assets suggested a higher yield and lower values than is reflected by the actual sales during the quarter. This data was Lehman's own up-to-date information, whereas the theoretical models in use at the time relied on data from third parties which was often stale.

The procedures used by the Product Control Group (PCG) have already been set out. The Group used a variety of methodologies, depending on the kind of asset and available information to verify the pricing information provided by the business desk. The PCG had to abandon its usual method of using a mock securitization model based on the latest Lehman deal. But that market ceased to operate in early 2008, so the Principal Transactions Group (PTG) had to consider other methods.

The PCG based this on an examination of the PTG's own price testing analysis, in which the PCG identified a $\$ 70 \mathrm{~m}$. net negative variance, equal to about 0.5 per cent of Lehman's $\$ 15 \mathrm{bn}$ commercial portfolio, but Lehman's marks for the assets tested were higher than the test prices, suggesting an over-valuation. Furthermore, for the second quarter, Lehman produced an analysis of the sales data with the carrying values of assets remaining on the balance sheet. It concluded that the average selling yield was lower than the average carrying yield of the remaining assets, so that the prices which Lehman achieved on actual sales were higher than the assets on its balance sheet. But the Examiner noted that there was great variation on positions even in the single asset category, so that there would have to be a position-specific analysis to determine the exact value. However, his analyses suggested that the PCG had sufficient sales data to price the commercial book during the second quarter of 2008. Indeed the available sales data indicate that Lehman's marks for these assets were conservative. He added that, assuming the assets sold were 'comparable to the remaining assets, the Commercial Book as of May 31, 2008 was undervalued in the light of the second quarter available. Lehman relied on sales data to support the valuation of Commercial assets at the quarter end. ${ }^{28}$ 
The bankruptcy filing took place just fifteen days after the third quarter ended, so less information was available. The process used by PCG was similar, with reliance on sales data where that was available, and using the Large Loan and Junior Note pricing models in the absence of such data. Even in that quarter, sales took place in each asset class, including large loans (floating and fixed rate), mezzanine (fixed and floating rates), B-notes and securities, totalling $\$ 2,468 \mathrm{~m}$. The review of these models shows that for the Large Loan Floating Rate model, there was a $\$ 45 \mathrm{~m}$. positive variance, or a 0.7 per cent potential undervaluation of $\$ 6.3 \mathrm{bn}$ worth of positions. For the Junior Note price testing model, there was an $\$ 87 \mathrm{~m}$. net negative variance, or a potential 3.5 per cent over-valuation of $\$ 2.5 \mathrm{bn}$ worth of positions. Taking actual sales into account, the pricing models on average predicted a higher spread than the average selling spread, indicating that the positions were marked at lower prices than similar positions sold during the third quarter. The Examiner therefore concluded that 'there is insufficient evidence' to show that 'the Commercial Book valuations as of the third quarter of 2008 were unreasonable. ${ }^{29}$

However, it appears that there were greater difficulties in valuing the debt and equity investments in real estate projects, which were intended to be held while the underlying real estate was developed and improved. This work was carried out by the PTG. These assets were not for sale and were relatively illiquid even when the commercial real estate market was booming. They were apparently valued through a combination of financial projections and 'gut feeling', owing to the fact that each asset was unique, compounded by the lack of sales data for the debt and equity positions. There was, the Examiner records, considerable disagreement about the necessity of valuing these assets at a price they could be sold to a third-party investor in 2007 and 2008. Instead the valuation of these assets depended on whether the development was proceeding according to the project's business plan. Even so, this methodology did result in an approximate write-down of $\$ 1.1 \mathrm{bn}$ out of $\$ 8.6 \mathrm{bn}$ PTG portfolio at the end of 2007.

This was partly because TriMont, Lehman's real estate adviser, had to provide models with an internal rate of return (IRR) for each development. These were designed to assess the value of the real estate by discounting the projected cash flows of the completed project to a present value. The model was not completed until July 2008. Even when it was developed, it used a yield which did not necessarily match the investors' required rate of return (market-based interest rates) as at the particular measurement date. The application of this model led to the decision that it would be appropriate to write down PTG assets by $\$ 714 \mathrm{~m}$. for the third quarter of 2008, although Jonathan Cohen believed that there was a 
$\$ 500 \mathrm{~m}$. limit on write-downs for the third quarter, but he did not advise anyone senior to him, apart from Gerard Reilly, Global Head of Risk Management, that he and Anthony Barsanti, PTG Senior Vice President responsible for marking the PTG positions, had calculated write-downs beyond $\$ 500 \mathrm{~m}$. so about another $\$ 214 \mathrm{~m}$. of write-downs were not taken.

Here the Examiner concluded that 'there is sufficient evidence to support a finding, for purposes of solvency analysis, that certain of Lehman's PTG valuations as of May 31, 2008 and August 31, 2008 were unreasonable. He stated that his 'analysis of these assets does not present an opinion as to the fair value of these assets as of May or August 2008, but simply investigates the assumptions and practices Lehman used in valuing the selected PTG assets and reaches a conclusion as to the reasonableness of those assumptions and practices. ${ }^{30}$

The Examiner also provides an overview of Lehman's Principal Transactions. These were primarily debt or equity investments in real estate development and improvement projects. These had no cash flow, as the land was due to be developed, or less cash flow than was projected to be generated on development, such as the conversion of rental apartments to condominiums. The plan was to exit from these positions when the project was completed and produce a cash flow through leasing or sales. Development projects were usually completed between two to five years after Lehman provided the funding, after which the underlying property was usually sold. Its main relationships were with developers with a proven track record of successfully completing projects.

Lehman was aware that these were higher risk/higher return projects, due to the lack of stabilized cash flows and the risk that the development might not be completed according to the business plan. This portfolio increased in size, and the average position became riskier during 2006 and 2007. The levels of risk also increased because of the increased focus of land development projects; the focus on California and other boom markets and a greater proportion of equity investments. Investment in development of land for residential purposes brought higher returns than, for example, office upgrades. The company's risk exposure increased as it took equity stakes in developments, up from 26 per cent in 2004 to 34 per cent in 2005 and 2006. During 2007, noticing that the market was 'dropping like a stone', as one executive put it, approvals for new deals were not given and originators stopped submitting deals where Lehman was not sufficiently senior in the debt structure.

Lehman originated fewer positions during the last quarter of 2007, a trend that continued into 2008, and also wrote down the value of PTG investments by $\$ 137 \mathrm{~m}$. in the fourth quarter of 2007 , by $\$ 271 \mathrm{~m}$. in the first quarter of 2008 , 
and by $\$ 302 \mathrm{~m}$. in the second quarter of 2008 . At that time, the company held 741 positions in the PTG portfolio, and Lehman valued these positions at $\$ 8.5 \mathrm{bn}$, with an average position of $\$ 11 \mathrm{~m}$. Approximately 33 per cent of the overall portfolio (210 positions) was in land for development, with condos and conversions at 21.7 per cent. The size of this portfolio decreased slightly between the second and third quarters of 2008 , to 690 positions valued at $\$ 7.8 \mathrm{bn}$ as a result of a further write-down in the third quarter. Although Lehman slowed down the pace of new originations, the company still held a large number of relatively risky positions originated between 2004 and 2007.

\section{Conclusions as to the reasonableness of Lehman's valuation of the PTG portfolio}

The Examiner found sufficient evidence to support his view that 'Lehman did not appropriately consider market-based yield when valuing PTG assets in the second and third quarters of 2008.'The company did not introduce a methodology that used market-place yields quickly enough, and even when it did implement such a methodology (IRR models), the yields in the IRR models reflected the weighted average of the contractual interest rate for debt at origination and Lehman's expected rate of return rather than market-based rates.

The Examiner set out the 'conflicting statements' as to whether 'PTG assets were valued at the price at which the asset should be sold, and, in particular, whether the valuation took into account the market-based yield that would be required by an investor in the light of the then-current market conditions' Despite that, he concluded that Lehman's assets were not so marked in the second and third quarters of 2008. One of his interviewees, Anthony Barsanti, the person who was primarily responsible for determining PTG marks, said that 'he did not know whether PTG assets could be sold at the price at which they were marked, and stated that he had not really thought about it'! $!^{31}$ Other senior staff, such as Jonathan Cohen, involved in valuing Lehman's assets, took the view that PTG was not required to mark assets at 'fire sale' prices, pointing out that a significant number of positions were carried at 90 per cent par value and stated that a 'willing buyer was not going to pay that. ${ }^{32}$ Over 90 per cent of Lehman's third quarter write-downs were based on credit impairment, with only 7 per cent related to yield. However, both Jonathan and Kenneth Cohen stated that the valuation for credit impairment would take into account yield impairment. The switch to IRR models in the third quarter of 2008 led to a large drop in the value 
of the assets, showing that they had been overvalued in the second quarter. The valuations or 'marks' in that second quarter were not 'reasonable assessments of fair value' for the purposes of a solvency analysis. Kenneth Cohen and Jonathan Cohen regarded the PTG marks as representing fair value, because they had concluded that PTG 'was not required to mark these illiquid assets, backed by non-stabilized real estate, at prices they could sell for during a sharp market downturn'. The logic behind this was that Lehman had a 'policy against valuing assets based on distressed sales. ${ }^{33}$ This, however, misses the point entirely. The requirement to mark assets at fair value for the purposes of solvency or SFAS 157 is not overridden by Lehman's plans for the sale of the asset.

\section{Archstone and SunCal}

These were two major commercial real estate investments made by Lehman. In 2003, Mark Walsh introduced a set of 'bridge equity' deals in which the bank held on to the equity until it sold its equity stake, which had to be as soon as possible; otherwise the bank risked being left 'holding the baby'. Lehman was able to charge 4 per cent for its equity investments, above the going market rate of 1.5 per cent. Walsh pursued and gained an exclusive partnership with the SunCal Companies of Irvine, California. The company bought land, mainly in its home state, sought approval for residential development, prepared the land (infrastructure, services and communications) and then sold it to residential construction companies at a profit.

Walsh wanted an exclusive partnership with SunCal, although other investment banks wanted to be part of the deal. Walsh lent SunCal $\$ 2 \mathrm{bn}$ on the SunCal Bakersfield site, a projected community development project, that was 10 per cent of the entire capital then, based only on the developer's blueprint and, not surprisingly, formed a close relationship with its founder, Boris Elieff. The site was never developed. On another occasion, in May 2006, land prices in California took a further hike, at the conclusion of the sale of a piece of land between Century City and Beverly Hills, for which SunCal paid $\$ 110.2 \mathrm{~m}$., outbidding Donald Trump's offer of $\$ 100 \mathrm{~m}$. Loans to the company were difficult to syndicate, owing to the difficulty of estimating future income streams. At one stage in 2006, Walsh invested about $\$ 140 \mathrm{~m}$. from funds into SunCal deals, and then, realizing that investors wished to withdraw the cash from the funds, he arranged for those investors to withdraw their funds. Even though that exercise made a profit, Lehman was left with even more risky assets on its balance sheet. 
It is worth noting that Lehman was not the only investment bank using bridge equity. In October 2006, Wachovia and Merrill Lynch pledged \$1.5bn for Tishman Speyer's \$5.4bn acquisition of Stuyvesant Town, a vast apartment complex in Manhattan. In February 2007, Goldman Sachs, Morgan Stanley and Bear Stearns put up \$3.5bn into the Blackstone Group’s \$32bn deal to buy Equity Office Properties Trust. JP Morgan were also involved in equity bridge loans, as was Citibank, often acting jointly with other banks, such as Morgan Stanley and Citigroup. JP Morgan offered a \$1bn equity bridge in an LBO offer for a Texas Utility, TXU Corp. Lehman also owned part of the Rockefeller Foundation and the Chrysler Building, together with Bank of America's Strategic Ventures and Barclays Capital. The only difference between Lehman and the other investment banks was the size of their commitments to commercial real estate. Lehman ended up with $\$ 29 \mathrm{bn}$ commercial real estate exposure on its books in the second quarter of 2008, 30 per cent more than Deutsche Bank and Morgan Stanley, and 70 per cent more than Goldman Sachs.

Equity bridge financing has been available for many years, but it became fashionable again between 2000 and 2006, when the size and frequency of the deals rang warning bells amongst some bankers and officials at the Federal Reserve. The Office of the Comptroller of the Currency (OCC) described the increased risks associated with equity bridges as 'a heavy responsibility on sponsors to sell equity to limited partners and other investors, potential contractual limits on sales rights, a limited secondary private equity market and the questionable ability to place the equity if the deal sponsor has tried and failed. ${ }^{34}$ Almost a year before that, in response to a question from a banker in the audience at the conference, Chairman Bernanke had stated that 'there are some significant risks associated with private equity including bridge loans. We are looking at that. ${ }^{35}$ Not very hard, one might conclude from the fact that little action was taken, at least as far as investment banks were concerned. Perhaps the fact that the Federal Banking Agencies had already issued the 'Final Guidance on Concentrations in Commercial Real Estate Handling' in December 2006 might have been regarded as sufficient. ${ }^{36}$

The focus of the Guidelines was on the degree of concentration and less on the method of acquiring the assets. It was 'guidance' as well, designed to influence bank behaviour in a more flexible and timely way than is possible with official rule-making. It was unusual guidance, in that it set very specific threshold limits describing the concentration levels at which increased supervisory attention to a bank's risk management procedures for its CRE lending would receive much closer attention from bank supervisors. That might lead to a downgrade of the 
bank's official supervisory ratings, together with a greater involvement of supervisors in a bank's decision-making processes. This, however, only applied to state member banks and bank holding companies and their non-bank subsidiaries. That still left the investment banks and private equity companies beyond the ambit of such guidance. Even then, the guidance does not seem to have come fully into force until 4 January 2007, according to the Federal Reserve Bank's supervisory notice.

Mark Walsh continued to make deals in the commercial real estate market. He was described by a former Lehman employee as 'holding the keys to the kingdom'; as another real estate financier who had worked with Lehman put it, Walsh had 'extraordinary authority to commit capital as he saw fit. ${ }^{37}$ Lehman's partnership with SunCal continued, but by September 2008, Lehman was left with $\$ 2.2 \mathrm{bn}$ in exposure to SunCal on its books. Gone were the days when others were clamouring for a piece of SunCal and when Lehman was able to syndicate $\$ 320 \mathrm{~m}$. in loans on several SunCal projects in California.

The Examiner focused on Archstone, the largest investment. SunCal together with Lehman had invested through its complex company structure in California and many sites had either not been developed or were left with only part of the agreed work with the local authority undertaken by 2008 . Following the collapse of Lehman a number of SunCal companies became insolvent or filed for Chapter 11 in November 2008.

Lehman, together with Tishman Speyer, agreed to acquire Archstone, a publicly traded Real Estate Investment Trust (REIT) on 29 May 2007, and the deal was finalized on 5 October 2007. Its portfolio of properties included expensive apartment buildings in metropolitan areas such as New York, Washington DC, San Francisco, Seattle and Boston. On 31 December 2007, Archstone owned 154 apartment communities, composed of 46,566 units, some of which were still under construction. Just before the sale, it was the second largest publicly traded apartment REIT in the USA, measured by market capitalization and enterprise value.

Lehman funded the approximately $\$ 5.4 \mathrm{bn}$ purchase price. Archstone was its largest commercial real estate investment. Tishman put up only $\$ 250 \mathrm{~m}$. of its own equity. The Examiner records that Lehman brought Bank of America to the acquisition, and on the Commitment Date each institution agreed to provide half of the debt financing and to purchase half of the bridge equity, although Bank of America did not purchase a permanent equity position. On 11 June 2007, Barclays agreed to purchase 15 per cent of the debt and 15 per cent of the bridge equity, and on 2 July 2007, agreed to increase its participation to 
25 per cent. Barclays' commitments came out of Bank of America's share, and did not affect Lehman's potential exposure to Archstone. As of 2 July 2007, commitments for debt (excluding mortgage and assumed debt) and bridge debt were: Lehman: 47 per cent, BofA: 28 per cent and Barclays: 25 per cent. It was a difficult deal to complete, given that the institutional market for investments backed by commercial real estate was 'virtually closed'. William Hughes, Managing Director of Loan Syndication, added that, 'We will have to devise a strategy to syndicate this risk to bankers. That said, many of the logical candidates on the bank side are wounded from the current sell-off. This is clearly a deal we shall all have to watch carefully. ${ }^{38}$

However, when the deal was closed, on 5 October 2007, the asset-level debt was secured by mortgages on Archstone's properties and comprised of $\$ 9.5 \mathrm{bn}$ of first lien mortgage debt, $\$ 1.1 \mathrm{bn}$ of mezzanine mortgage debt and $\$ 1.4 \mathrm{bn}$ of existing mortgage debt. Archstone had $\$ 4.6 \mathrm{bn}$ bridge equity and $\$ 500 \mathrm{~m}$. of permanent equity. As part of the closing, $\$ 1.4 \mathrm{bn}$ of properties from Archstone's portfolio were sold and the proceeds used to repay acquisition debt. This reduced Archstone's value from $\$ 23.6$ bn to $\$ 22.2$ bn at closing. In September 2007, Freddie Mac agreed to purchase approximately $\$ 1$ bn of Archstone mortgage debt and Fannie Mae committed to purchase $\$ 7.1$ bn of Archstone's mortgage debt. In an interview with the Examiner, Mark Walsh and Lisa Beeson, then Head of Real Estate Mergers and Acquisitions in Lehman's Investment Banking Division, said that 'these decisions confirmed the underlying soundness of the acquisition', an astonishing statement, given the extent of Fannie Mae's and Freddie Mac's failures, which even then were coming to light. ${ }^{39}$ At the closing, Lehman, BoA and Barclays had syndicated only $\$ 71 \mathrm{~m}$. of bridge equity, that is, 1.5 per cent of the aggregate $\$ 4.6$ bn bridge equity commitment. After closing, the three banks did not syndicate any bridge equity and only syndicated $\$ 43 \mathrm{~m}$. of term loans. At the closing date, most of Lehman's positions ( 86 per cent) were term loans (42 per cent) and bridge/permanent equity ( 44 per cent). That meant that 86 per cent of Lehman's investment was subordinated to over half (55 per cent) of Archstone's capital structure. This put Lehman in a vulnerable position, since it meant that, especially with regard to its equity positions, it was exposed to the risk of significant losses, if the Archstone investment fell over time (or gains) if its value increased.

The three banks had agreed a 'side letter' in October 2007, setting out the terms and conditions of 'price flex'. This is a way of facilitating a sale or syndication of a loan by the initial lender without incurring a loss. The side letter in this case allowed the Archstone lenders, after 24 March 2008, to require Archstone to alter 
the pricing of the applicable loans (spreads, margins or fees) in order to achieve a successful syndication of such loans. The Bank of America held an escrow account, originally funded with $\$ 39 \mathrm{~m}$. to equal any losses suffered based on the market price of unsold Archstone debt. It had to be marked to market by BoA at the beginning of every month, and if it was too small, then Archstone had to put additional funds into the account. The only deposit before Lehman collapsed was $\$ 33 \mathrm{~m}$. on 28 February 2008 , so the account had a balance of about $\$ 74 \mathrm{~m}$. at the beginning of August 2008. The Examiner commented that he did not find sufficient evidence to support a determination that Lehman's valuation of Archstone debt options covered by price flex was unreasonable. ${ }^{40}$

After the Archstone closing, Lehman held \$5.4bn in Archstone positions: $\$ 3.0 \mathrm{bn}$ of debt and \$2.4bn of equity, designated as Lehman's 'funded exposure', because they constitute the amount of debt that Lehman invested, net of any repayments of debt by Archstone. After that, Lehman took three valuationrelated write-downs on its Archstone positions. At the end of March 2008, Lehman took a $\$ 200 \mathrm{~m}$. write-down on the bridge equity and $\$ 50 \mathrm{~m}$. on permanent equity. In May 2008, the company took a $\$ 90 \mathrm{~m}$. write-down on bridge equity and a $\$ 10 \mathrm{~m}$. write-down on permanent equity. Finally in August 2008, Lehman took a $\$ 110 \mathrm{~m}$. write-down on bridge equity and a $\$ 15 \mathrm{~m}$. write-down on permanent equity. However, the Examiner points out that a review of the weighted average is better than a mark on any specific position, because Lehman was determined to value all its Archstone holdings in aggregate; for example, because an assessment of Lehman's bridge equity on its own would not separate the change in value due to the price flex mechanism, which meant that the equity absorbed any loss of value in debt.

However, the Examiner did not find any evidence that Lehman was engaged in an effort to systematically value its Archstone commitments before that date. ${ }^{41}$ This was true even at the end of their financial year at 30 November 2007. The trigger for a careful valuation was an article in Barron's, 'Apartment House Blues' on 21 January 2008, in which the author, Andrew Bary, argued that the Archstone transaction could be 'disastrous for Wall Street firms and other equity investors ... as rent increases will slow even in relatively strong markets, and that the value of Archstone equity could be zero. Bary also pointed out that

Archstone is a classic example of a good company with a bad balance sheet. It has more than $\$ 16 \mathrm{bn}$ of debt, and its interest expense is running at more than $\$ 1 \mathrm{bn}$ annually. Cash flows from its properties was running at just a $\$ 700 \mathrm{~m}$. rate 
in the second quarter of 2007, meaning that the company is burning cash. The LBO sponsors told potential lenders in September that Archstone was actually covering its interest expense, but that was only because of a pre-funded $\$ 500 \mathrm{~m}$ interest reserve.

It is odd that none of this seems to have entered into the discussions about the issue of debt or the interest expenses due, although even after due diligence was conducted, the size of the total debt remained at $\$ 6.6 \mathrm{bn}$ against the total enterprise value of $\$ 20.2 \mathrm{bn}$ without any reference to interest expenses.

Not surprisingly, the article was a wake-up call for Lehman, leading to plans to ramp up the disposition programme in 2008. Meetings took place between BoA, Barclays, Lehman and Tishman Speyer. The latter proposed allocating more capital to developments with higher returns whilst selling its core portfolio apartment complexes, which would be difficult to achieve at that time. The collapse of Bear Stearns in March, meant that'all of the large deals we were trying to put together earlier this year have been unsuccessful to date', as Tishman Speyer advised in another memo.

The March 2008 valuation reflected Lehman's view that the risks associated with Archstone's generation of its projected cash flows had increased. There was an additional $\$ 100 \mathrm{~m}$. write-down in May 2008. Ian Lowitt in the earnings call set out the methodology, emphasizing comparisons with AvalonBay, another similar company to which an independent research company ascribed a higher capitalization than Archstone's. Barclays and Bank of America complained that the reduction in the valuation of Archstone's equity positions was lower than the mark they were using. The write-downs for the third quarter were, as already stated, $\$ 110 \mathrm{~m}$. for bridge equity and $\$ 15 \mathrm{~m}$. in permanent equity. With regard to the valuations during 2008, the Examiner found that in each quarter, 'for the purposes of a solvency analysis that Lehman's valuations for its Archstone bridge and permanent equity investments were unreasonable', but that there was no 'intent to produce incorrect values or to conduct the valuation process in a reckless manner.' 